Danuta Gibas-Krzak

\title{
Neoosmanizm - jako idea w tureckiej polityce zagranicznej na tle sytuacji geopolitycznej Bałkanów pod koniec XX i na początku XXI w.
}

Po „zimnej wojnie” nastapiła zmiana w polityce zagranicznej, prowadzonej przez Turcję sensu largo, zwłaszcza w odniesieniu do Półwyspu Bałkańskiego. Zdaniem wielu analityków, działania Ankary należy oceniać pozytywnie, bowiem sa one odbierane jako wspieranie krajów tej części Starego Kontynentu na drodze integracji euroatlantyckiej, jak również ich rozwoju politycznego, gospodarczego i kulturalnego. Dla państwa tureckiego Bałkany stanowia region aktywnej polityki, której celem jest zbudowanie pomostu między Turcją a Europą Zachodnia. Ankara wciąż jest zainteresowana wstapieniem do Unii Europejskiej (UE), natomiast aktywność na tym obszarze ma świadczyć o jej potencjalnych możliwościach - ważnych dla procesów stabilizacji Bałkanów (zwłaszcza Zachodnich), co ma służyć umocnieniu pozycji Ankary w jej relacjach z Brukselą.

${ }^{1}$ Ł. Reszczyński, Geopolityczna emancypacja Turcji $i$ jej wptyw na Batkany Zachodnie, 10 VII 2010, http://www.geopolityka.org/publikacje/491-geopolityczna-emancypacja-turcji-i-jej-wplyw-na-balkany-zachodnie (dostęp 20 II 2014). Od października 2005 r. do początku 2014 r. Ankara otworzyła 13 z 35 rozdziałów negocjacji z UE, ale został zamknięty tylko jeden, dotyczący nauki i badań naukowych. Nie zmniejsza to jednak tureckich ambicji, choć największą przeszkodą na tej drodze nadal pozostaje sceptyczna postawa Niemiec oraz nierozwiązana kwestia cypryjska, 
Wielu naukowców i polityków na Zachodzie podkreśla, iż odbywa się to $\mathrm{w}$ ramach soft power, stosowanej zarówno przez UE, jak i przez Turcję. Z kolei analitycy na Bałkanach Zachodnich sądza, iż asertywność Turcji w tym regionie może jednocześnie implikować niebezpieczeństwo związane ze wzrostem tureckiej dominacji, zwłaszcza że Ankara, tworząc fundamenty nowej polityki po „zimnej wojnie” odwołuje się bezpośrednio do dziedzictwa Imperium Ottomańskiego, które rozciagało swoje panowanie na Bałkanach - począwszy od średniowiecza aż do wojen bałkańskich (1912-1913)². Nie można więc zaprzeczyć, że Turcja w perspektywie historycznej była agresorem, a następnie okupantem na Bałkanach, dlaczego więc obecnie nie miałaby zmierzać do przywrócenia swoich wpływów i dążyć ponownie do dominacji? ${ }^{3} \mathrm{Na}$ ten aspekt doktryny nowej polityki zagranicznej tego państwa zwraca uwagę wielu analityków serbskich, którzy podkreślaja, iż Turcja pragnie odbudować dawną strefę wpływów na Bałkanach.

Celem niniejszej analizy jest próba odpowiedzi na pytanie, czy poprzez swoje działania Turcja zainicjowała politykę

Nowy rozdział negocjacji akcesyjnych UE z Turcja, 6 XI 2013, http:// www.forbes.pl/nowy-rozdzial-negocjacji-akcesyjnych-ue-z-turcja,artykuly,165970,1,1.html (dostęp 20 II 2014).

${ }^{2}$ Prawie dwa wieki zajął Imperium Osmańskiemu podbój Bałkanów, lecz w drugiej połowie XVI w. niemal cały Półwysep Bałkański znalazł się już pod panowaniem tureckim, K. Bieniek, Polityka zagraniczna Turcji wobec państw batkańskich, Torun 2008, s. 21.

${ }^{3}$ Wielu analityków podkreśla, iż Turcja zakłada podejmowanie pokojowych środków rozwiązania konfliktów na drodze dyplomatycznej, umacniając $\mathrm{w}$ ten sposób bezpieczeństwo w regionie. Nie zwraca się natomiast uwagi na aspekt imperialny, który występuje w działaniach Ankary, T. Żornaczuk, Polityka Turcji wobec Bałkanów Zachodnich i jej znaczenie dla relacji $z$ Uniq Europejska, [w:] Turcja $i$ Europa. Wyzwania $i$ szanse, red. A. Szymański, Warszawa 2011, s. 202 i nast. 
Neoosmanizm - jako idea w tureckiej polityce zagranicznej... 223

ekspansji na Półwyspie Bałkańskim, która może zdestabilizować porządek ustanowiony po „zimnej wojnie”, jednocześnie zagrażając bezpieczeństwu i suwerenności państw tego regionu?

\section{Geopolityczne uwarunkowania Bałkanów po „zimnej wojnie”}

Należy zgodzić się z tymi naukowcami, którzy stoją na stanowisku, że Bałkany trzeba rozpatrywać jako specyficzny obszar, posiadający naturalne predyspozycje geograficzne oraz złożoną wewnętrzną i zewnętrzną strukturę antropogeniczna, które determinuja jego dynamikę geopolityczna. Odrębność tego regionu polega na tym, że charakteryzuja go szczególnie wyraźne podziały, przeciwieństwa, permanentne roszczenia terytorialne, rozbieżne strefy interesów, ingerencja wielkich mocarstw, polaryzowanie ekonomiczne, dualizm „łaczenia i rozciagania się” oraz „izolowania i oddzielania”4. Mozaika kulturowo-religijna zdeterminowana jest przez występujący na tym obszarze rozłam religii chrześcijańskiej z najbardziej wysuniętym na zachód punktem zasięgu prawosławia, znajdującym się najbliżej Watykanu, jak również fakt, iż terytorium to stanowi najkrótszy szlak bezpośredniego przedostawania się islamu na Stary Kontynent ${ }^{5}$. Podziały

${ }^{4}$ J. Cvijić, Balkansko poluostrvo i južnoslovenske zemlje. Osnovi antropogeografije, Beograd 1966, s. 8-9.

${ }^{5} \mathrm{Z}$ historycznego punktu widzenia Bałkany podlegały złożonym procesom geopolitycznym. Do zakończenia II wojny światowej poddane zostały zjawiskom zdobywania i podbijania. Po II wojnie światowej wystawione zostały na wpływy Wschodu i Zachodu, a po zakończeniu „zimnej wojny” do dziś uczestniczą w procesie globalizacji, M. Sretenović, Geopolitički položaj Zapadnog Balkana, „Vojno delo” [proleće] 2010, god. LXII, s. 58-61. 
narodowościowe, etniczne, kulturowe i religijne sa nadal najbardziej konfliktogennymi czynnikami, które determinuja dzieje Półwyspu Bałkańskiego.

Analitycy serbscy podkreślaja, że nagłe zmiany, wynikające z kresu świata dwubiegunowego, wstrząsnęły obszarem Bałkanów z siła, którą można porównać do trzęsienia ziemi $\mathrm{z}$ epicentrum usytuowanym $\mathrm{w}$ wielonarodowej federacyjnej Jugosławii, która zniknęła z mapy politycznej Europy. Wojna domowa w Jugosławii zmieniła bowiem konfigurację i uwarunkowania geopolityczne na tym obszarze. Na terytorium obejmującym byłą Socjalistyczną Federacyjną Republikę Jugosławii (SFRJ) - w wyniku burzliwych procesów powstało w krótkim czasie sześć państw (z możliwościa dalszego ich podziału). Tę część półwyspu współcześnie zaczęto określać Bałkanami Zachodnimi, które to pojęcie najpierw funkcjonowało nieformalnie w języku polityków, aby wkrótce mieć już oficjalne zastosowanie, zarówno w relacjach międzynarodowych, jak i nauce. Za przyczyny wprowadzenia tej terminologii uznać można rozpad Jugosławii oraz europejskie procesy integracyjne. Bałkany Zachodnie - jako całość terytorialna, wyodrębniona z powodu specyficznych cech politycznych, ekonomicznych i bezpieczeństwa, przez wspólnotę międzynarodową - obejmują nowo powstałe państwa na obszarze byłej SFRJ, łącznie z Albania, lecz bez Słowenii ${ }^{6}$.

Serbscy badacze podkreślaja, iż zasady, które przyjęto tworzac pojęcie Bałkany Zachodnie - są dyskusyjne. Z jednej strony można założyć, że stanowią one regionalnie zintegrowany obszar przestrzenny, w skład którego wchodzą kraje, pozostajace w poprzednim dziesięcioleciu w konflikcie zbrojnym. Kolejna eksplikacja wskazuje, że desygnat Bałkanów Zachodnich stanowi spuściznę po państwach byłej Jugosławii. W tym sensie

${ }^{6}$ Ibidem, s. 56. 
są one „tworem sztucznym”, efektem kreacji europolityków z Brukseli, których zamiarem było wyodrębnienie niestabilnego obszaru na Starym Kontynencie, znajdującego się na drodze transformacji systemowej ${ }^{7}$. Ten tok myślenia uzasadnia fakt, iż nie istnieja przecież w stosunkach międzynarodowych pojęcia, takie jak: Bałkany Wschodnie, Północne i Południowe ${ }^{8}$.

Tworząc nową strukturę geograficzno-polityczna, unijni urzędnicy przyczynili się do dekompozycji Bałkanów. Może zakładali, że - gdy wszystkie kraje tego regionu przystapią do UE - Bałkany „rozpłyna” się w Europie i w ten sposób nastapi kres konfliktów, które wzbudzają niepokój cywilizowanego świata. Ale zachodni politycy nie biora pod uwagę specyfiki tego regionu, którego sprzeczności kulturowe, etniczne i religijne sa tak duże, że nie można ich zlikwidować ani odgórnymi decyzjami, ani w stosunkowo krótkim czasie. Nowo powstałe państwa, nie radzac sobie z wieloma wyzwaniami, moga doprowadzić do kolejnych konfliktów - nie tylko w skali regionu, lecz również Europy ${ }^{9}$.

Geopolityczna pozycja Bałkanów wyznaczona jest przez ich położenie w znaczacym pod względem strategicznym

${ }^{7}$ Bałkany Zachodnie - jest to obszar o powierzchni 264 tys. km², z 24 mln mieszkańców. Pięć z sześciu państw Bałkanów Zachodnich posiada dostęp do Morza Adriatyckiego. Węzły komunikacyjne: morawsko-vardarski, marički i Düres-Tirana-Skopje-Sofia-Morze Czarne mają duże znaczenie nie tylko dla tego regionu, ale i dla Europy oraz Azji. Całkowita geoprzestrzeń Bałkanów Zachodnich stanowi węzeł komunikacyjny, w którym kluczową pozycję zajmuje Serbia, ibidem, s. 56-57.

${ }^{8}$ Ibidem.

${ }^{9}$ Być może burzliwy XX w. nie zakończył się jeszcze w tym regionie, wyznaczony przez wojny bałkańskie 1912-1913, aż do bombardowania Serbii przez NATO w 1999 r. Jego kontynuacją stały się bowiem kolejne wydarzenia na Bałkanach, doprowadzające do ich dalszej fragmentaryzacji - powstanie Czarnogóry w 2006 r. oraz Kosowa w 2008 r., M. Sivignon, Les Balkans. Une géopolitique de la violence, Paris 2009, s. 48-49. 
obszarze rimlandu (obszar krańcowy). Sprawia to, że decydujacy wpływ na losy tego terytorium maja aktorzy zewnętrzni, którzy usiłuja realizować własne interesy strategiczne. Trzeba podkreślić, iż o współczesnej geopolitycznej sytuacji Półwyspu Bałkańskiego decyduja determinanty globalne (światowe), kontynentalne (europejskie) oraz regionalne (bałkańsko-panońskie).

Procesy geopolityczne, zachodzące na Bałkanach, stymulowane sa przez czynniki pozabałkańskie i wewnątrzbałkańskie, zazwyczaj wzajemnie poprzeplatane i połączone wspólnymi interesami i celami. Należy pamiętać, że po rozpadzie bipolarnej struktury doszło do osłabienia czynników regionalnych, które gwarantowały bezpieczeństwo, co spowodowało powstanie „geopolitycznej próżni”. Wykorzystując kryzys jugosłowiański jako pretekst, pozabałkańskie siły, zainteresowane kontrolą tego obszaru, przyspieszyły swoje działania, sprawiając, że Bałkany stały się polem bitwy dla mocarstw, które pragnęły rozszerzyć swoje strefy oddziaływania ${ }^{10}$. Rywalizacja o ten obszar najważniejszych graczy na arenie międzynarodowej implikuje szereg przeciwności. Dotyczą one rozbieżnych interesów na poziomie globalnym Stanów Zjednoczonych i Europy (zwłaszcza Niemiec). Na poziomie kontynentu europejskiego obejmują rywalizację między Wielką Brytania, Francja, Niemcami i Rosją. Można także wymienić przeciwności występujące między głównymi graczami w ramach organizacji międzynarodowych i prawa międzynarodowego ${ }^{11}$. Mocarstwa dążą do zwiększenia sfery swoich wpływów poprzez kontrolę Bałkanów (Niemcy, Wielka Brytania, Francja, Rosja, Turcja), a większość narodów bałkańskich nadal zakłada możliwość

${ }^{10}$ S. Šušić, Balkanski geopolitički košmar, Beograd 1995, s. 32.

${ }^{11}$ A. Davutoglu, Strategijska dubina - međunarodni položaj Turske, „Politeia” [Banja Luka] 2011, god. I, br. 2, s. 190-191. 
realizacji własnych projektów tzw. wielkich państw (,Wielka Albania”, „Wielka Chorwacja”, „Wielka Serbia”, „Wielka Bułgaria” czy „Wielka Rumunia”"12).

\section{„Strategiczna głębia” - nowa asertywność Ankary na arenie międzynarodowej}

Wyjątkowe znaczenie geopolityczne Turcji wynika z jej położenia na skrzyżowaniu cywilizacji i obszarów, które należą do najbardziej niestabilnych na świecie. W okresie „zimnej wojny" państwo to prowadziło politykę jednotorowa, zachowując prozachodnią orientację $e^{13}$. Następnie rozpoczęło politykę balansowania między wizjami świata proponowanymi przez Europę i Stany Zjednoczone. Obietnice szybkiej integracji z UE sprawiły, iż Ankara w latach 2000-2005 weszła w „erę westernizacji”, która charakteryzowało podjęcie reform proeuropejskich. Zakończyła się ona jednak wraz z dojściem do władzy Angeli Merkel i Nicolasa Sarkozy'ego, którzy nie odnieśli się przychylnie do akcesji Turcji do Uniii ${ }^{14}$.

W ciagu dwóch dekad porządku pozimnowojennego nastapiła jednak istotna ewolucja w prowadzonej przez Turcję polityce zagranicznej. Od 2002 r., po dojściu do władzy Partii Sprawiedliwości i Rozwoju (Adalet ve Kalkınma Partisi, AKP), zaczą ją wyznaczać nowy kierunek, nazwany „strategiczna głębią" (tur.: stratejik derinlik). Twórca tej doktryny jest Ahmet Davutoğlu, były doradca premiera Recepa Tayyipa

${ }^{12}$ M. Sretenović, op. cit., s. 60 i nast.

${ }^{13}$ A. Szymański, Polityka zagraniczna Turcji w latach 2007-2009: kontynuacja czy zmiana?, „Polski Przegląd Dyplomatyczny” 2009, nr 2 (48), s. 46.

${ }^{14}$ M. Herbut, Turcja między Wschodem a Zachodem, [w:] Polityka zagraniczna. Aktorzy. Potencjaty. Strategie, red. nauk. T. Łoś-Nowak, Warszawa 2011, s. $317-321$. 
Erdoğana i minister spraw zagranicznych, a od 2014 r. premier. Ta pragmatyczna strategia rozwijała się pod wpływem założeń neoosmanizmu, który zyskał na znaczeniu za rządów prezydenta Turguta Özala oraz premiera Necmettina Erbakana ${ }^{15}$. Niektórzy naukowcy wskazuja, iż świt idei neoosmanizmu można dostrzec także we wcześniejszych działaniach Turcji na arenie międzynarodowej. Istnieje hipoteza, że pojęcie neoosmanizmu zostało wprowadzone przez greckich ekspertów po inwazji tureckiej na Cypr w 1974 r. ${ }^{16}$, do której doszło notabene wbrew woli USA i NATO ${ }^{17}$.

Należy podkreślić, że „strategiczna głębia” posiada dwa wymiary: historyczny i geograficzny. Historyczny odnosi się do spuścizny osmańskiej, geograficzny natomiast dotyczy geopolitycznego położenia Turcji między Wschodem a Zachodem, w Europie i Azji, w sassiedztwie Afryki, Bałkanów, Bliskiego Wschodu i Kaukazu Południowego ${ }^{18}$. „Strategiczna

${ }^{15}$ A. Szymański, Polityka zagraniczna Turcji..., s. 47.

${ }^{16}$ M. Jevtić, Neoosmanizam versus panislamizm, „Politeia” [Banja Luka] 2011, god. I, br. 2, s. 34. Darko Tanasković wskazał, że pierwsza faza rozwoju neoosmanizmu wystapiła już w około 10 lat po śmierci Kemala Atatürka (1881-1938), kiedy rozpoczą się stopniowy proces reislamizacji państwa. W latach 50. XX w. można mówić o początkach neoosmanizmu, co znalazło wyraz we wprowadzeniu do szkół podstawowych i średnich nauki islamu, rozpoczęciu na szeroką skalę budowy meczetów oraz propagowaniu religii muzułmańskiej w programach radiowych, D. Tanasković, Neoosmanizam. Doktrina i spolnopolitička praksa, Beograd 2010, s. 20-21.

${ }^{17}$ Interwencja wojskowa Turcji doprowadziła do objęcia przez Turków kontroli nad 40\% obszaru wyspy i taki stan nie uległ zmianie do dziś, K. Bieniek, System partyjny Republiki Turcji w latach 1950-2011, Warszawa 2013 , s. 151.

${ }^{18}$ Ahmet Davutoğlu wskazał, iż celem polityki tureckiej ma być demokratyzacja wewnętrzna, dobre relacje z sąsiadami (,zero problemów” we wzajemnych stosunkach), aktywność, wielowymiarowe działanie, pewność siebie, ale i predylekcja do kompromisu, prowadzenie rytmicznej dyplomacji, elastyczne podejście do priorytetu, jakim jest bezpieczeństwo narodowe, 
Neoosmanizm - jako idea w tureckiej polityce zagranicznej... 229

głębia”, najogólniej mówiąc, oznacza wzrost aktywności politycznej Turcji na obszarach obejmujacych terytorium byłego Imperium Ottomańskiego, na Bliskim Wschodzie, Bałkanach, Azji Centralnej, Kaukazie i w Afryce Północnej. Zgodnie z ta doktryna, Turcja powinna wykorzystać dorobek Imperium Osmańskiego, jak też swoje geopolityczne położenie do kształtowania wielowektorowej polityki zagranicznej oraz odgrywania roli pomostu między Wschodem a Zachodem, z jednoczesnym przywództwem na terytorium swych dawnych posiadłości ${ }^{19}$. Tureccy politycy podkreślaja, iż w obliczu nowego porządku globalnego należy zwrócić uwagę na dialog między cywilizacjami, nie obawiając się zagrożenia ze strony islamu. Turcja - ze względu na swoje usytuowanie - jest zarazem państwem śródziemnomorskim, jak też europejskim, leży bowiem na skrzyżowaniu cywilizacji, pozostaje kulturowo związana ze Wschodem i Zachodem, przysługuje jej więc status państwa „centralnego”. Sprawia to, iż powinna odgrywać zasadniczą rolę w umacnianiu pokoju na świecie ${ }^{20}$.

Część analityków zwraca uwagę, iż aktywność Turcji na Bałkanach związana jest bezpośrednio z mniejszym zainteresowaniem tym regionem ze strony Stanów Zjednoczonych, jak również tendencja wzrostu, niezależnych od wpływów amerykańskiego hegemona, działań w prowadzeniu polityki odpowiadającej interesom państwa tureckiego. Swoista próba sił między oboma krajami nastapiła w czasie ataku na Irak

przedkładanie środków soft power nad hard power, A. Szymański, Polityka zagraniczna Turcji..., s. 47-50. Turecki polityk podkreślił ponadto, iż jego państwo nie może oddalić się od Bałkanów - rozumianych jako historyczna strefa wpływów Turcji, w której po zakończeniu „zimnej wojny” doszło do nowej równowagi sił i strategicznej transformacji, A. Davutoglu, op. cit., s. $189-198$.

${ }^{19}$ A. Szymański, Polityka zagraniczna Turcji..., s. 47.

${ }^{20}$ M. Herbut, op. cit., s. 324. 
w 2003 r., kiedy Ankara odmówiła zgody na transport wojsk koalicyjnych przez jej terytorium. Probierzem pogorszenia się stosunków na linii Stany Zjednoczone-Turcja stała się też sprawa kurdyjska. Kontakty Amerykanów z Partią Pracujących Kurdystanu (Partiya Karkerên Kurdistan, PKK), podejrzenia o sprzedaż broni bojownikom kurdyjskim, zwłoka w likwidowaniu obozów tego ugrupowania na terenie północnego Iraku - ochłodziły wzajemne relacje, a wobec Waszyngtonu zrodziło się podejrzenie, iż ten staje się (lub może się stać) protektorem Kurdów ${ }^{21}$. Do napięć w stosunkach amerykańsko-tureckich doszło także podczas kampanii wyborczej Baracka Obamy, który wyborcom ormiańskiego pochodzenia obiecywał, że Kongres USA przyjmie rezolucję, w której rzeź Ormian, dokonana w państwie tureckim w latach 1915-1916, zostałaby uznana za ludobójstwo. Wywołało to ostrą reakcję w Ankarze, powodujac m.in. odwołanie z Waszyngtonu tureckiego ambasadora oraz zawieszenie prac turecko-amerykańskiej rady biznesu ${ }^{22}$. Relacje Stany Zjednoczone-Turcja są także delimitowane przez politykę Ankary wobec Izraela. Potępienie przez nią bombardowania Strefy Gazy w latach

${ }^{21}$ Ömer Taşpinar wskazał na coraz większą asertywność tureckiej polityki zagranicznej, polegająca na zabezpieczeniu własnych interesów strategicznych. W tym kontekście istotne stają się pytania: Czy Ankara powinna nadal zabiegać o, niedające się przewidzieć, członkostwo w UE? Czy Turcję nadal łączy ze Stanami Zjednoczonymi taka sama percepcja najważniejszych zagrożeń dla ładu międzynarodowego? Ö. Taşpinar, The Rise of Turkish Gaullism: Getting Turkish-American Relations Right, „Insight Turkey" 2011, vol. 13, no. 1, s. 11-16. Na tle konfliktów destabilizujących sytuację w Azji Mniejszej Turcja wydaje się być jednak najbardziej stabilnym partnerem Stanów Zjednoczonych, zwłaszcza gdy jej trzech sasiadów (Syria, Iran i Irak) stanowi istotny problem dla bezpieczeństwa międzynarodowego, J. Krajcarz, NATO, USA a sprawa turecka, 25 V 2012, http://balkanistyka.org/nato-usa-a-sprawa-turecka/ (dostęp 20 II 2014).

${ }^{22}$ D. Tanasković, op. cit., s. 54. 
2008-2009 oraz w 2012 r., nazwanie go przez turecką dyplomację zbrodnią przeciwko ludzkości - stało w sprzeczności z polityką prowadzona przez Waszyngton ${ }^{23}$.

Jednocześnie należy podkreślić, iż wielowektorowy charakter polityki Turcji sprawia, że umacnia się jej pozycja na arenie międzynarodowej. W ocenie analityków państwo to, podobnie jak Chiny, dazży do ustanowienia wielobiegunowego porządku świata, podkreślając rolę potencjału gospodarczego, który w zglobalizowanym świecie odgrywa coraz większą rolę. Ankara w znacznym stopniu angażuje się w budowę więzi ekonomicznych i strategicznych z Chinami, Rosja, Indiami, państwami Bliskiego Wschodu oraz Afryki ${ }^{24}$.

\section{Turecka ofensywa polityczna, ekonomiczna i kulturalna na Bałkanach}

Po „zimnej wojnie” nowe uwarunkowania w relacjach międzynarodowych sprawiły, że dla celów strategicznych Ankary niezwykle istotne stały się stosunki regionalne. Początkowo największe jej zainteresowanie zostało skierowane w stronę Bliskiego Wschodu i Kaukazu, wkrótce jednak kolejnym celem Turcji stały się Bałkany, traktowane jako trzeci regionalny priorytet $\mathrm{w}$ nowej doktrynie polityki zagranicznej. W okresie „zimnej wojny” relacje te były limitowane przez ówczesne stosunki Wschód-Zachód, chociaż szereg ciekawych inicjatyw zrealizowano nawet w najgorętszej jej fazie (np. podpisanie w 1954 r. Paktu Bałkańskiego przez Turcję, Grecję

${ }^{23}$ Turcja wspiera Palestyńczyków i potępia Izrael, 16 XI 2012, http:// www.polskieradio.pl/5/3/Artykul/726216,Turcja-wspiera-Palestynczykow-i-potepia-Izrael (dostęp 20 II 2014).

${ }^{24}$ A. Szymański, Polityka zagraniczna Turcji..., s. 62. 
i Jugosławię, który stanowił nadzieję na zmianę układu sił na tym terytorium) ${ }^{25}$. Obecnie Bałkany zyskały uznanie jako najważniejszy region - ze względu na położenie geograficzne, więzi historyczne, kulturowe i ekonomiczne oraz kontakty międzyludzkie ${ }^{26}$.

Serbski naukowiec Darko Tanasković podkreślił, że nowe zbliżenie Turcji do Bałkanów nie koliduje z polityką Stanów Zjednoczonych, które dały Ankarze carte blanche w tym regionie, aby mogła tam odgrywać rolę stabilizatora sytuacji politycznej, zwłaszcza w krajach muzułmańskich, w których zdobyła znaczne wpływy. Ponadto istnieje hipoteza, że wzrost wpływów Turcji na Bałkanach ma być rodzajem zadośćuczynienia za jej brak sukcesów w procesie integracji z Unią Europejska. Może to także świadczyć o słabości polityki Brukseli wobec tego regionu, którego problemów nie potrafi rozwiąaćéc ${ }^{27}$. Turcy maja jednak wobec niego znacznie większe ambicje - chcieliby stanowić alternatywę dla tych krajów bałkańskich, które nie są członkami UE. Takie stanowisko wyraziła Ankara na forum państw Procesu

${ }^{25}$ Sytuacja uległa zmianie po 1989 r., kiedy najważniejszymi graczami w konflikcie jugosłowiańskim stały się: UE i zjednoczone Niemcy, a następnie Rosja i Stany Zjednoczone. Rola, jaką Waszyngton odegrał w zakończeniu wojny w Bośni i Hercegowinie, a następnie w konflikcie NATO-Jugosławia w 1999 r., pozwoliła temu mocarstwu zdobyć silna pozycję na Bałkanach. Podporządkowanie Albanii oraz marionetkowego quasi-państwa Kosowa zapewniły Waszyngtonowi możliwość sprawowania kontroli w tym regionie.

${ }^{26} \mathrm{~S}$. Constantinides, Turkey: the emergence of a new foreign policy - the neo-ottoman model, „Journal of Political and Military Sociology” 1996, vol. 24, no. 2, s. 323. Jednym z głównych celów polityki tureckiej jest umacnianie relacji z państwami bałkańskimi, uczestnictwo w ich procesach stabilizacyjnych, a także rozwój szlaków komunikacyjnych wiodących na Zachód, T. Żornaczuk, op. cit., s. 203.

${ }^{27}$ D. Tanasković, op. cit., s. 86-87. 
Neoosmanizm - jako idea w tureckiej polityce zagranicznej... 233

Współpracy w Południowo-Wschodniej Europie (South-East European Cooperation Process, SEECP), którego zadaniem jest koordynowanie działań związanych z transformacja systemowa na Bałkanach oraz integracja państw tego regionu z UE i NATO ${ }^{28}$.

Należy zauważyć, że o pozytywnym oddziaływaniu polityki „strategicznej głębi” świadczy wiele tureckich inicjatyw na Bałkanach Zachodnich. Należy do nich podpisana w 2010 r. w Stambule przez prezydentów Turcji, Serbii, Bośni i Hercegowiny deklaracja, która wskazuje na szczególną rolę Turcji jako gwaranta stabilizacji na Bałkanach. Za najważniejszą część tego dokumentu uznano integralność granic Bośni i Hercegowiny, a także zapewnienie normalizacji stosunków tego kraju z sąiadami ${ }^{29}$.

Turcja odnosi znaczne sukcesy w dziedzinie bezpieczeństwa regionalnego - wspierała przystapienie Chorwacji i Albanii do NATO w 2009 r., a w 2010 r. najaktywniej poparła wysiłki Bośni i Hercegowiny o włączenie jej do Planu Działań na rzecz Członkostwa (MAP) w 2010 r..$^{30} \mathrm{O}$ zaangażowaniu Ankary w procesy stabilizacyjne świadczy obecność żołnierzy i funkcjonariuszy policji w misjach unijnych w Bośni i Hercegowinie - „Althea”, Kosowie - EULEX, KFOR, UNMIK, Macedonii - „Concordia”, EUPOL (European Union Police Mission) „Proxima” ${ }^{31}$.

Po zakończeniu walk w byłej Jugosławii Turcja przyjęła rolę mediatora, który pomaga rozwiązać konflikty, aby

${ }^{28}$ Ł. Reszczyński, op. cit.

${ }^{29}$ J. Krajcarz, Turcja: bałkański „,neo-osmanizm” droga stabilizacji politycznej $i$ gospodarczej, 27 IV 2012, http://balkanistyka.org/turcja-balkanski-neo-osmanizm-droga-stabilizacji-politycznej-i-gospodarczej/ (dostęp 20 II 2014).

${ }^{30}$ T. Żornaczuk, op. cit., s. 203-204.

${ }^{31}$ M. Herbut, op. cit., s. 320. 
poprawić relacje między państwami Bałkanów Zachodnich. Dotyczy to zwłaszcza stosunków bilateralnych między Belgradem a Sarajewem, jak również między Chorwacją a Bośnią i Hercegowina ${ }^{32}$. Ankara była zaangażowana w przyjęcie przez Skupsztinę Serbii w marcu 2010 r. rezolucji o Srebrenicy, w której Belgrad potępił zbrodnie wojenne, przepraszając rodziny ofiar. Tureccy politycy stwierdzili, że fakt ten stanowi „krok historyczny”, natomiast poprawę w stosunkach bośniacko-serbskich należy uznać za ważny czynnik stabilizacji na Bałkanach ${ }^{33}$.

Władze Kosowa podkreślaja, iż Turcja jest istotnym promotorem ich kraju na arenie międzynarodowej. Ankara uznała jego niepodległość jako jedno z pierwszych państw już w dzień po jej ogłoszeniu (18 lutego 2008 r.), będąc adwokatem Prisztiny na forum Organizacji Współpracy Islamskiej. Z Kosowem Turcja ma najlepiej na Bałkanach rozwinięte stosunki polityczne, gospodarcze i kulturowe, tam też obecność silniejszego partnera okazuje się najbardziej widoczna. Turcja jest drugim po Albanii państwem, które podpisało z Kosowem umowę o liberalizacji wizowej. Zdobyła także pozycję najważniejszego inwestora gospodarczego i handlowego ${ }^{34}$.

Wsparcie, udzielone przez Turcję wojskom NATO podczas nalotów na Jugosławię w $1999 \mathrm{r} \cdot{ }^{35}$ oraz szybkie uznanie przez

${ }^{32}$ 七. Reszczyński, op. cit.
${ }^{33}$ T. Żornaczuk, op. cit., s. 214.
${ }^{34}$ Ibidem, s. $207-208$.
${ }^{35}$ Wielu autorów podaje sprzeczne informacje na temat udziału Ankary w bombardowaniach Jugosławii przez NATO w 1999 r. Tomasz Żornaczuk podkreślił, że rząd w Ankarze ogłosił swój udział w bombardowaniach dopiero w połowie maja 1999 r., a wkład w operacje polegał na uczestnictwie tureckich myśliwców w nalotach oraz udostępnieniu baz dla lotnictwa NATO, ibidem, s. 206. Serbscy analitycy natomiast zwrócili uwagę, że naloty Sojuszu na Jugosławię były prowadzone m.in. z baz ulokowanych w Turcji, nie uwzględniając udziału w nich żołnierzy tureckich, S. Smiljanić, 
Ankarę niepodległości Kosowa, w znacznym stopniu utrudniły relacje z Belgradem. Dopiero w marcu 2009 r. doszło do pełnej normalizacji stosunków bilateralnych. Stało się to dzięki wizycie ministra spraw zagranicznych Serbii, Vuka Jeremicia, w Turcji. Ankara oświadczyła wówczas, że Serbia i Turcja stanowiq czynnik pokoju i stabilności na Batkanach. W lipcu 2009 r., podczas wizyty w Serbii ministra spraw zagranicznych Turcji, relacje między oboma krajami zostały określone jako strategiczne partnerstwo. Deklaracjom politycznym towarzyszyły umowy gospodarcze. Jednocześnie podpisano także dokumenty o współpracy technicznej i finansowej oraz w dziedzinie opieki społecznej. W tym samym czasie w Nowym Pazarze delegacja turecka spotkała się z lokalnymi politykami muzułmańskimi ${ }^{36}$. Wizyta $\mathrm{w}$ Serbii ówczesnego prezydenta Turcji, Abdullaha Güla, pod koniec 2009 r. doprowadziła do intensyfikacji współpracy politycznej, gospodarczej i kulturalnej między oboma państwami, ponadto została wprowadzona praktyka regularnych spotkań ministrów spraw zagranicznych Serbii, Turcji oraz Bośni i Hercegowiny ${ }^{37}$.

Turecka ekspansja na Bałkanach ma charakter wielowymiarowy. Jej aspekt kulturalny dotyczy przede wszystkim Bośni i Hercegowiny, Albanii i Kosowa, które stanowia główne centra oddziaływania tureckiej soft power. W Sarajewie $\mathrm{w}$ ostatnich latach powstały dwa tureckie uniwersytety, sfinansowane częściowo z funduszy biznesu związanego z Partią

\footnotetext{
Agresija NATO. Ratno vazduhoplovstvo i protivvazdušna odbrana u odbrani otadbine, Beograd 2009, s. 142.

${ }^{36}$ T. Żornaczuk, op. cit., s. 211-212.

${ }^{37}$ N. Jeftić-Šarčević, Zapadni Balkan u projekciji "Turske strateške vizije", http://www.doiserbia.nb.rs/\%28X\%281\%29A\%28JHj-LghazwEkAAAAMTJjMmM0MDYtNzMwNi00YzI0LWE3YTEtOGE3MGVIN2Q0ZjYxpsgDi1LWILSHVYcPPyioZiNkQvs1\%29\%29/img/doi/0025-8555/2010/0025-85551004691J. pdf (dostęp 20 II 2014).
} 
Sprawiedliwości i Rozwoju: International University of Sarajevo oraz International Burch University, gdzie można m.in. studiować język i literaturę turecką. W ramach programów naukowych propaguje się idee zacieśniania stosunków między Turcja a Bałkanami, zaś połowę studiujących stanowia Turcy $^{38}$. Na ulicach Sarajewa zauważa się wpływy tureckie. Świadczą o tym m.in. liczne reklamy tanich lotów do Stambułu - tam i z powrotem. W bośniackiej telewizji do najpopularniejszych seriali należy turecka produkcja, przedstawiająca dzieje sułtana Sulejmana Wspaniałego, jednego z najwybitniejszych władców Imperium Ottomańskiego ${ }^{39}$.

Kolejny wymiar tureckiej ekspansji na Bałkanach obejmuje działania ekonomiczno-inwestycyjne, które skierowane sa - oprócz wymienionego wcześniej Kosowa - przede wszystkim do Chorwacji, Czarnogóry i Serbii. Turcja w 2012 r. zajęła trzecie miejsce pod względem inwestycji zagranicznych $\mathrm{w}$ Chorwacji ${ }^{40}$. Inwestuje także $\mathrm{z}$ powodzeniem w Serbii. Za przykład tego niech posłużą projekty infrastrukturalne w rejonie Nowego Pazaru, na zrealizowanie których rząd turecki udzielił znacznej pożyczki ${ }^{41}$. Politycy z Czarnogóry w wielu wypowiedziach wyrażali nadzieję, że wzrost zaangażowania tureckiego biznesu na Bałkanach może stać się katalizatorem, doprowadzając do rozwiązania problemów gospodarczych regionu, jak też związanych z nimi - politycznych i społecznych ${ }^{42}$.

${ }^{38}$ Symbolem International University of Sarajevo jest pomnik Mehmeda Zdobywcy, który podbił Bośnię w 1463 r., Turecka ekspansja na Batkanach?, 27 III 2013, http://www.portal.arcana.pl/Turecka-ekspansja-na-balkanach,3721.html (dostęp 20 II 2014).
${ }^{39}$ Ibidem.
${ }^{40}$ Ibidem.
${ }^{41}$ T. Żornaczuk, op. cit., s. 216.
${ }^{42}$ J. Krajcarz, Turcja: batkański... 
Neoosmanizm - jako idea w tureckiej polityce zagranicznej... 237

Turcję łączą również przyjazne relacje z Macedonia. Jednak większość tureckich inicjatyw jest skierowana tam w stronę ludności albańskiej, dla której organizacje pozarządowe prowadzą wiele programów edukacyjnych. Z Ankary płyną także fundusze na konserwację zabytków z epoki osmańskiej ${ }^{43}$.

Po zakończeniu „zimnej wojny” Turcja nawiązała bliższe stosunki również z innymi państwami bałkańskimi: Rumunią i Bułgaria, których integrację z NATO i UE wsparła na arenie międzynarodowej. We wrześniu $1991 \mathrm{r}$. Turcja i Rumunia zawarły Umowę o Przyjaźni i Współpracy. 6 maja 1992 r. Ankara podpisała Traktat o Przyjaźni, Współpracy i Bezpieczeństwie z Sofia. Obydwaj sygnatariusze pod wpływem Turcji w 1998 r. uznali PKK za organizację terrorystyczna ${ }^{44}$.

Jeśli chodzi natomiast o współpracę z Grecja, to ze względu na konflikt cypryjski jest ona bardziej skomplikowana. Jednak także i w przypadku tego kraju Turcja realizuje ją opierając się na zasadzie „zero problemów z sąsiadami”.

${ }^{43}$ Ibidem.

${ }^{44}$ K. Bieniek, Polityka zagraniczna Turcji..., s. 118, 122-123. Współpraca z Bułgarią rozwija się na wielu płaszczyznach. W czasie kryzysu ekonomicznego Turcy wystapili z propozycjami licznych inicjatyw gospodarczych, z których największe znaczenie ma porozumienie w dziedzinie współpracy energetycznej, w tym dotyczące budowy gazociągu, który przez Turcję będzie dostarczał surowce znad Morza Kaspijskiego. Innym wymiarem bilateralnych stosunków jest współpraca w dziedzinie ochrony środowiska, zabytków, turystyki oraz współdziałanie w zakresie budowy centrów kultury, J. Krajcarz, Nowy rozdziat wspótpracy gospodarczej Turcji i Butgarii, 20 IV 2012, http://balkanistyka.org/nowy-rozdzial-wspolpracy-gospodarczej-turcji-i-bulgarii/ (dostęp 20 II 2014). Także z Rumunią Turcja rozwija wszechstronną współpracę, dla której nowym otwarciem było podpisanie 12 grudnia 2011 r. deklaracji o strategicznym partnerstwie obu państw. Przewiduje ona intensyfikację współdziałania w sektorach politycznym, gospodarczym, bezpieczeństwa, kultury i edukacji, T. Dąborowski, Rumunia intensyfikuje relacje $z$ Turcja, 21 XII 2014, http://www.osw.waw.pl/pl/publikacje/analizy/2011-12-21/rumunia-intensyfikuje-relacje-turcja (dostęp 20 II 2014). 
W kontekście istniejących napięć politycznych dużą rolę w relacjach bilateralnych odgrywa dobrze rozwinięta grecko-turecka współpraca gospodarcza, zwłaszcza w sektorze energetycznym ${ }^{45}$.

\section{Neoosmanizm - turecka dominacja na Bałkanach?}

W ocenie wielu polskich, jak też zachodnich analityków, asertywność Ankary jest zjawiskiem pozytywnym, sprzyjajacym procesom stabilizacji na Bałkanach (zwłaszcza Zachodnich). Wielowiekowe panowanie Osmanów w tym regionie sprawiło, że zajmuje on kluczowe miejsce w obecnych relacjach Ankary z Europa. Zasadnicza rola Bałkanów w polityce „strategicznej głębi” polega na specyficznym ich postrzeganiu przez Turków, traktujaccych ten obszar jako dziedzica osmańskiej Rumelii, który posiada kluczowe znaczenie dla kreowania koncepcji zarówno neoosmanizmu, jak i europejskiego charakteru Turcji ${ }^{46}$.

${ }^{45}$ A. Szymański, Polityka zagraniczna Turcji..., s. 75. Zob. A. Adamczyk, Problem cypryjski - stanowisko Greków cypryjskich, [w:] Turcja i Europa..., s. $125-152$.

${ }^{46}$ D. Tanasković, op. cit., s. 88. Termin „Bałkany” jest zwiąany z tureckim podbojem i opanowaniem ziem Półwyspu przez Imperium Ottomańskie. Turcy zwrócili szczególną uwagę na gęsto zalesione góry jako na główną cechę zdobywanych terytoriów Europy Południowo-Wschodniej, które nazwali Balkanlar (liczba mnoga od tureckiego słowa „balkan”, czyli pasmo górskie pokryte lasem). Rumelia to nazwa polityczno-administracyjna tego terytorium, utworzona od starotureckich słów: rum - co oznacza grecki, i eli - czyli obszar. Turcy uznali te ziemie początkowo za greckie, nie tylko ze względu na występowanie na znacznej części podbitego terytorium „religii greckiej”, ale także związków handlowych, społecznych i kulturowych z cywilizacja grecka, H. Batowski, Batkany. Kraje i narody batkańskie, „Etnografia Polska” 1966, t. X, s. 118-119. 
W związku z taką percepcją osmańskiej spuścizny naukowcy z Serbii zwracaja uwagę na pewne aspekty polityki zagranicznej Turcji, które świadczą o mogącym wystapić zagrożeniu turecką dominacją w regionie Bałkanów. Grupa badaczy serbskich, zwiazana z uniwersytetami w Belgradzie i Banja Luce, uważa, że ekspansywna polityka turecka niesie ze soba szereg niebezpieczeństw, związanych z jej antyserbskim charakterem, rewizja postanowień z Dayton oraz wspieraniem ugrupowań terrorystycznych poprzez fundamentalistów islamskich.

Zdaniem D. Tanaskovicia, polityka prowadzona przez Turcję, choć nosi nazwę „strategicznej głębi”, w istocie stanowi doktrynę neoosmanizmu, zgodnie z którą kraj ten na „euroazjatyckiej szachownicy" dąży do zdobycia pozycji państwa centralnego w nowym pozimnowojennym porządku. Politycy tureccy głosza, iż ich państwo nie może mieć charakteru peryferyjnego, posiada bowiem odpowiedni potencjał, taki jak: demokratyczny porządek, dynamiczne społeczeństwo, stabilna klasa średnia, dobrze prosperująca gospodarka, wysoko rozwinięta naukowa i technologiczna infrastruktura ${ }^{47}$.

W ocenie D. Tanaskovicia, działania tureckie można określić jako realizację doktryny neoosmanizmu, która stanowi ideologiczne połaczenie islamizmu, turkizmu i osmańskiego imperializmu ${ }^{48}$. W tureckiej literaturze przedmiotu występuje pogląd, że neoosmanizm mógł się rozwijać, gdyż kemalizm nie był zdolny wypracować takich wartości, które zaspokoiłyby potrzeby społeczeństwa tureckiego w zakresie kodeksu

${ }^{47}$ D. Tanasković, op. cit., s. 37-38.

${ }^{48}$ Ibidem, s. 14-15, 19. Zdaniem A. Szymańskiego, tożsamość islamska nie stanowi istotnej dominanty, dzięki której ukształtowała się polityka „strategicznej głębi”. Decyduje ona jednak o asertywności polityki tureckiej i sprzyja aktywności w stosunkach z krajami i organizacjami muzułmańskimi, A. Szymański, Polityka zagraniczna Turcji..., s. 50-51. 
moralnego $\mathrm{w}$ niosacej nowe wyzwania epoce globalizacji. $\mathrm{W}$ tej sytuacji kemalizm połączył się z neoosmanizmem, bowiem jedna z cech kemalizmu jest turkocentryczny nacjonalizm. Wspólnymi przymiotami tych dwóch doktryn sa patriotyzm i lojalność wobec państwa, istotne zwłaszcza w sytuacji, gdy Zachód prowadzi niekonsekwentna politykę wobec europejskich ambicji Turcji i jej chęci bycia państwem nowoczesnym, co prowadzi do rozwoju swoistego tureckiego nacjonalizmu. Ten w literaturze przedmiotu nazwany jest „tureckim gaullizmem" 49 .

Serbscy naukowcy zwracają uwagę, iż dla wykrystalizowania się ideologii neoosmańskiej istotne znaczenie miało wystapienie ministra A. Davutoğlu w październiku 2009 r. podczas konferencji w Sarajewie, dotyczącej tureckiego dziedzictwa i muzułmańskiej wspólnoty na Bałkanach. Polityk ów podkreślił wtedy, iż historia Imperium Osmańskiego świadczy o szczególnym znaczeniu Bałkanów w dziejach świata. W jego ocenie, tylko w okresie podboju przez Turków region ten doświadczył pełnego sukcesu. W związku z tym wyraził on chęć odbudowy tureckich Bałkanów, podkreślając, że w Turcji mieszka więcej Bośniaków niż w Bośni, więcej Czeczenów niż w Czeczenii, więcej Abchazów niż w Abchazji - a dla wszystkich tych narodów Turcja stanowi ojczyznę. Region Bałkanów powinien więc zintegrować się tak samo jak Bliski Wschód i Kaukaz, zgodnie z zasadami regionalnego i światowego pokoju. Davutoğlu zwrócił uwagę, iż dla Turcji integralność terytorialna Bośni i Hercegowiny jest równie ważna, jak niepodległość Turcji, natomiast bezpieczeństwo Sarajewa jest tak samo istotne, jak bezpieczeństwo Stambułu ${ }^{50}$.

${ }^{49}$ Zob. Ö. Taşpinar, op. cit.

${ }^{50}$ D. Tanasković, op. cit., s. 45-46. 
Należy zgodzić się z oceną D. Tanaskovicia, który uznał, że Turcja, aktywizując się na terytorium swojego historycznego zaplecza (hinterlandu), daje sobie prawo historycznej odpowiedzialności za sytuację na Bałkanach. W ten sposób może zachodzić podejrzenie o chęć zbudowania przez Ankarę nowego ładu imperialnego - Pax Ottomana ${ }^{51}$. Zdaniem A. Davutoğlu, Turcja bez oddziaływania na wydarzenia zachodzące na Bałkanach nie jest w stanie zachować swojej terytorialnej integralności oraz otworzyć się na świat ${ }^{52}$.

Trzeba podkreślić, że Ankara posiada największe wpływy w krajach muzułmańskich na Bałkanach: Albanii, Kosowie oraz Bośni i Hercegowinie. Jak zaznaczył Davutoğlu, to Albańczycy i Bośniacy uważani są za dziedziców osmańskiej cywilizacji, stanowiac par excellence rdzeń tureckiej polityki zagranicznej na Bałkanach, dwa fundamenty, na których opiera się tradycyjne osmańsko-tureckie działanie polityczne w tym regionie. Bośnia i Hercegowina oraz Albania stanowią więc w tureckim geopolitycznym modelu klucz do Bałkanów. Dlatego też Ankara kieruje tam swoje wysiłki, aby wzrastał ich potencjał oraz poczucie stabilizacji ${ }^{53}$.

Takie podejście wywołuje podejrzenie o brak obiektywizmu w relacjach międzynarodowych Ankary z innymi państwami bałkańskimi oraz nieufność wobec pokojowych intencji głoszonych przez ten kraj. W czasie wojny w Bośni i Hercegowinie Turcja opowiedziała się po stronie muzułmanów, wspierając na arenie międzynarodowej działania Boszniaków. W grudniu $1992 \mathrm{r}$. domagała się na forum konferencji ds. byłej Jugosławii oraz NATO, aby przeciwko Serbom użyć wojsk Sojuszu oraz żądała zakwalifikowania serbskich

${ }^{51}$ Ibidem.

${ }^{52}$ M.B. Marković, Strategijska dubina Ahmeta Davutoglua, „Politeia” [Banja Luka] 2011, god. I, br. 2, s. 187.

${ }^{53}$ D. Tanasković, op. cit., s. 93. 
ataków na muzułmanów jako zbrodni przeciwko ludzkości ${ }^{54}$. W czasie wojny Turcja rywalizowała z Iranem o wpływy na terytorium Bośni i Hercegowiny - wspierała mudżahedinów, walczących w imię dżihadu, eskalując konflikty etniczne, z jej obszaru sprowadzano islamskich najemników, dostarczano broń oraz amunicję $e^{55}$.

Warto zwrócić uwagę na poglądy A. Davutoğlu, dotyczące istnienia trzech koncentrycznych kręgów (pierścieni) na Bałkanach. Środkowy krag, składajacy się z Kosowa, Albanii i Macedonii, stanowi scenę konfliktów, wynikających z podziałów albańskiej tożsamości etnicznej. Następny pierścień tworzą: Grecja, Serbia, Bułgaria, Turcja, Bośnia i Hercegowina. Państwa te w przypadku rozwoju kryzysu w środkowym kręgu, bezpośrednio włączają się w niego. Zewnętrzny pierścień buduja natomiast Chorwacja, Rumunia i Węgry. Rolą Turcji jest kontrolowanie sytuacji $\mathrm{w}$ tych pierścieniach, aby zachować równowagę strategiczną na Bałkanach ${ }^{56}$. Silna Albania oraz Bośnia i Hercegowina, do których może dołączyć Kosowo, stanowią podstawę bałkańskiej polityki Turcji, która, oddziałując na sytuację $\mathrm{w}$ tych państwach, może przeciwstawić się Rosji (poprzez wypieranie jej wpływów z Serbii i Bułgarii) oraz niemieckiej obecności na Bałkanach (zwłaszcza w Chorwacji i Słowenii) ${ }^{57}$.

Istotnym czynnikiem rozwoju nowych tendencji w polityce zagranicznej był wybór Mevlüta Çavuşoğlu na prezydenta

${ }^{54}$ K. Bieniek, Polityka zagraniczna Turcji..., s. 144.

${ }^{55}$ D. Džamić, Psi rata na Balkanu. Strani plaćenici u ratnim sukobima na prostorima bivše Jugoslavije, Beograd 2001, s. 206 i nast.

${ }^{56}$ Chorwacja jest istotna z tego powodu, gdyż może wpływać na wydarzenia zachodzące w Bośni i Hercegowinie. Węgry mogą oddziaływać na Wojwodinę, natomiast Rumunia, ze względu na swoje położenie, wywiera wpływ na równowagę każdego pierścienia, A. Davutoglu, op. cit., s. 212.

${ }^{57}$ D. Tanasković, op. cit., s. 93. 
Neoosmanizm - jako idea w tureckiej polityce zagranicznej... 243

Parlamentarnego Zgromadzenia Rady Europy w 2010 r. Ten turecki polityk juz w pierwszych publicznych wystapieniach oznajmił, iż jego kraj dąży do integracji z UE, chociaż jest świadomy, że droga do niej może być skomplikowana. W jego wypowiedziach pojawiła się krytyka obecnej sytuacji w Bośni i Hercegowinie, z powodu dysfunkcjonalności systemu podaytońskiego. Zdaniem Çavuşoğlu istnieje konieczność szukania nowych rozwiązań dla tego kraju, przy czym najlepszym wyjściem byłoby zwołanie międzynarodowej konferencji, która stanowiłaby Dayton Second, jak również przygotowanie nowej ustawy zasadniczej ${ }^{58}$.

Srdja Trifković z Wydziału Nauk Politycznych w Banja Luce wskazał, że polityka Turcji wykorzystuje ekspansywne koncepcje neoosmanizmu, chociaż Ankara temu zaprzecza. W ujęciu analityków serbskich, aspiracje Turcji nie mogą dłużej być zbieżne z interesami Stanów Zjednoczonych i UE. Sa także diametralnie przeciwne do interesów państw na Bałkanach, zwłaszcza prawosławnych. Realne jest bowiem zagrożenie, iż Turcja zbuduje na terytoriach dawnego Imperium Ottomańskiego potencjalnie wrogi wobec Słowian południowych i Zachodu blok państw islamskich, który jest zgodny z geopolitycznym paradygmatem tzw. Zielonego Korytarza - przewiduje on powstanie łańcucha państw islamskich (swoistego „islamistanu”) od Stambułu do Bośni i Hercegowiny, obejmującego także Albanię, Sandżak i Kosowo. Już teraz dochodzi do wzmocnienia etniczno-religijnej asertywności muzułmanów, popieranych przez Turcję $^{59}$. Należy podkreślić, że jest ona postrzegana przez wielu Bośniaków jako „duchowa i metafizyczna ojczyzna”, np. Mustafa Cerić, wielki mufti Bośni i Hercegowiny, nazywa Turcję „matką

${ }^{58}$ Ibidem, s. 14.

${ }^{59} \mathrm{~S}$. Trifkovic, Turkey as regional power: neo-ottomanism in action, „Politeia” [Banja Luka] 2011, god. I, br. 2, s. 89-91. 
Bośniaków", twierdzacc, iż muzułmanie zamieszkujący Bośnię sa jednocześnie Turkami i Bośniakami.

Władze w Ankarze zajęły także stanowisko wobec Kosowa, podkreślając, że jest to bratnie państwo ze względu na wspólnotę turecka, która obecnie liczy tam zaledwie 10 tys. osób ${ }^{60}$. Warto mieć na uwadze, że - zgodnie z teoria „strategicznej głębi" - Turcja nadała sobie prawo występowania w obronie wyznawców islamu na Bałkanach. Geopolitycznym instrumentem jej polityki ma być Organizacja Współpracy Islamskiej, która powinna także stanowić gwarancję nacisku na najważniejszych graczy na arenie międzynarodowej. Zadaniem Ankary ma być przedstawianie problemów muzułmanów na Bałkanach nie tylko w kontekście regionalnego zachowania ich tożsamości kulturowej oraz religijnej, ale przede wszystkim w ujęciu globalnych wyzwań stojących przed światem islamu. Dotyczy to zwłaszcza Albanii, Kosowa oraz Bośni i Hercegowiny. Bez konkretnego ich obrońcy mogłoby dojść nawet do likwidacji ich państwowości. W tureckiej wizji świata zwłaszcza Kosowo pojawia się jako szczególny problem związany z ochroną ludności wyznającej islam. W rozważaniach tureckich analityków ważne miejsce zajmuje rzekome ludobójstwo dokonane przez Serbów w Kosowie w latach 80. i 90. XX w., które jest „lejtmotywem” tureckiego dyskursu, podkreślającego serbskie zagrożenie dla muzułmańskiej tożsamości na Bałkanach ${ }^{61}$.

${ }^{60}$ T. Żornaczuk, op. cit., s. 216-217.

${ }^{61}$ A. Davutoglu, op. cit., s. 214-215. Wielu badaczy udowodniło, iż Serbowie nie prowadzili w Kosowie czystek etnicznych na Albańczykach, którymi uzasadniano interwencję NATO w Jugosławii w 1999 r., a do prawdziwej katastrofy humanitarnej doprowadziły dopiero bombardowania podjęte przez Sojusz, M. Waldenberg, Rozbicie Jugostawii. Jugostowiańskie lustro międzynarodowej polityki, Warszawa 2005, s. 290-291 i nast.; M.D. Luković, Kryzys kosowski oczyma Serbów. Bezpośrednie przyczyny, korzenie historyczne, przebieg $i$ konsekwencje, Belgrad 2000, s. 76-84. 
Neoosmanizm - jako idea w tureckiej polityce zagranicznej... 245

Serbscy analitycy zwracają uwagę, iż od czasu dojścia do władzy premiera Erdoğana ${ }^{62}$ wzrosły wpływy religii muzułmańskiej, co wskazuje na islamizację państwa tureckiego ${ }^{63}$. Warto zauważyć, że chociaż Turcja, zgodnie z obowiązującym prawem, pozostaje państwem świeckim, to jednak zasady laicyzmu zostały ograniczone przez konstytucje z $1961 \mathrm{r}$. i 1982 r. Stworzyły one bowiem podstawy do tego, aby islam był religią chroniona, jak i uprzywilejowana. Faktycznie Prezydium ds. Religijnych, chociaż zakłada neutralność, to jednak jest odpowiedzialne de facto tylko za religię muzułmańska, promuje islam w państwie, zaś obowiązkowe przedmioty w szkołach podstawowych i średnich z etyki i kultury religijnej w rzeczywistości stanowią zajęcia z islamu ${ }^{64}$.

Željko Vujadinović, historyk z Banja Luki, stwierdził, że ekspansja gospodarcza oraz tworzenie centrów kultury islamskiej w Bośni i Hercegowinie, Albanii oraz Kosowie sprawiaja, iż należałoby zadać pytania: Czy celem Turcji na Bałkanach jest stabilizacja, czy dominacja? Czy Bałkany sa potrzebne Turcji tylko jako droga tranzytowa na zachód

${ }^{62}$ Niezależni publicyści tureccy wskazują na zagrożenie islamizacją kraju, podkreślając, iż temu procesowi sprzyjają czołowi politycy. Warto zwrócić uwagę, że Erdoğan, gdy w 1997 r. był burmistrzem Stambułu, podczas wystapień cytował islamistyczny wiersz: Meczety sq naszymi koszarami, minarety naszymi bagnetami. Koputy sq naszymi hetmami. Wierni naszymi żotnierzami. Został wówczas skazany na karę więzienia za nakłanianie do agresji, Q. Ahmed, Wykastrować islamizm, 20 IX 2013, http://www.euroislam.pl/index.php/2013/09/wykastrowac-islamizm/ (dostęp 20 II 2014).

${ }^{63}$ S. Trifkovic, op. cit., s. 84.

${ }^{64}$ A. Szymański, System konstytucyjny Turcji, Warszawa 2006, s. 24. Do zadań Prezydium ds. Religijnych zalicza się m.in. opłacanie personelu meczetów, zarządzanie meczetami, organizowanie pielgrzymek do miejsc świętych, cenzurę opracowań religijnych, nadzorowanie konwersji na islam, T. Stuleblak, System polityczny Turcji, 2 III 2008, http://www.psz.pl/tekst-9262/ Tomasz-Stuleblak-System-polityczny-Turcji/Str-5 (dostęp 20 II 2014). 
Europy? Czy nie istnieje zagrożenie, że Europa przekaże Kosowo, Albanię, Bośnię i Hercegowinę jako turecką strefę wpływów, aby zrekompensować Ankarze brak zgody na jej akcesję do UE? Zdaniem tego naukowca, w ten sposób mógłby się powtórzyć scenariusz, który już miał miejsce w historii: w 1878 r. w wyniku postanowień kongresu berlińskiego Austro-Węgry otrzymały prawo okupowania Bośni i Hercegowiny ${ }^{65}$. Taki bieg wydarzeń tylko pozornie wydaje się nie do zaakceptowania. Podstawowa jego wadą są odmienne dziś realia międzynarodowe, lecz nie można wykluczyć takiego rozwoju wypadków, podczas których protektorat unijny dla Bośni i Hercegowiny, czy amerykański dla Kosowa i Albanii - zostanie zastapiony przez turecki (neoosmanizm).

Antyserbskie podejście analityków tureckich widać także w ocenie porozumienia w Dayton, które - w ich ujęciu - nie stanowi ostatecznego rozwiązania problemów Bośni i Hercegowiny, jest tylko wyjściem tymczasowym, operacja zamrażajacą istniejące konflikty narodowościowo-etniczne. Zdaniem tureckich analityków, Serbowie w Republice Serbskiej (w Bośni i Hercegowinie) posiadaja lepsze warunki rozwoju niż Muzułmanie w chorwacko-muzułmańskiej federacji. W ocenie Turków, porozumienie z Dayton legitymizowało czystki etniczne dokonane przez Serbów w czasie wojny i dało im możliwość budowy państwowości na tym terytorium, co stanowi niebezpieczeństwo dla równowagi strategicznej na Bałkanach ${ }^{66}$. W ten sposób w wizjach polityki zagranicznej Ankary dostrzec można elementy rewizjonistyczne wobec ustanowionego po wojnie ładu daytońskiego, a co za tym idzie - naruszenie podstaw bezpieczeństwa regionalnego na Bałkanach.

${ }^{65}$ Ž. Vujadinović, Neoosmanizam, reislamizacija i Balkan - dijalektičke napetosti, „Politeia” [Banja Luka] 2011, god. I, br. 2, s. 148-149.

${ }^{66}$ M.B. Marković, op. cit., s. 186. 
Zagrożenie powstaniem „islamistanu” łączy się także z aktywizacją organizacji terrorystycznych, współpracujacych z Al-Kaida. Na ten aspekt neoosmanizacji zwrócił uwagę amerykański analityk, John Schindler. Wielokrotnie ostrzegał on, że Bałkany mogą służyć jako baza treningowa dla organizacji terrorystycznych, związanych z radykalnym islamem, natomiast Bośnia i Hercegowina - niczym Afganistan w latach 80. XX w. - już stała się centrum szkoleniowym dla mudżahedinów. Alfred Sherman, były doradca premier Margaret Thatcher, uznał, że wojna w Bośni i Hercegowinie stworzyła odpowiednie warunki dla rozwoju islamu i jego penetracji w Europie Zachodniej, natomiast fundamentalistom islamskim umożliwiono budowę infrastruktury operacyjnej i organizacyjnej na Bałkanach ${ }^{67}$.

\section{Konkluzje i prognozy}

Po zakończeniu „zimnej wojny” potencjał Turcji oraz zmiana sytuacji geopolitycznej sprawiły, że wzrosło znaczenie tego kraju na arenie międzynarodowej. Niewątpliwie Ankara stara się zbudować stabilne stosunki z państwami na Bałkanach, wnosząc wkład $w$ ich demokratyzację i umacnianie bezpieczeństwa regionalnego, zwłaszcza poprzez poparcie udzielane $\mathrm{w}$ procesie integracji ze strukturami euroatlantyckimi. Sukcesy odniesione $\mathrm{w}$ tej dziedzinie trudno jednak przypisać oddziaływaniom tylko jednego promotora. Jednocześnie nie postrzega siebie jako obszaru peryferyjnego Europy, aspirujac do bycia najważniejszym graczem politycznym na Bałkanach oraz w basenie Morza Śródziemnego ${ }^{68}$. Czy faktycznie asertywność

\footnotetext{
${ }^{67}$ S. Trifkovic, op. cit., s. 91.

${ }^{68}$ N. Jeftić-Šarčević, op. cit.
} 
Turcji w tym regionie podyktowana jest wyłącznie dążeniem do wielobiegunowego ładu międzynarodowego na podobieństwo Chin i Rosji? Czy można bagatelizować, występujące w doktrynie „strategicznej głębi”, idee neoosmanizmu?

Politycy tureccy zwracaja uwagę, iż z panowaniem osmańskim wiąże się miniony dobrobyt Bałkanów. Tymi nadziejami staraja się przekonać do swojej polityki tamtejsze społeczeństwa, zwłaszcza muzułmanów zamieszkujących Bałkany ${ }^{69}$. Nie można zapominać, że region ten jest wciąż niestabilny, więc bardziej podatny na indoktrynację. W najgorszej sytuacji znajdują się Kosowo oraz Bośnia i Hercegowina. Niepokoje w północnym Kosowie, zwłaszcza w czterech gminach zamieszkałych przez Serbów, wciąż mogą być czynnikiem destabilizacji. Trzeba pamiętać, że niepodległość została ogłoszona jednostronnie przez Prisztinę i nie jest akceptowana przez Belgrad. Ten nadal uważa Kosowo za quasi-państwo, proklamowane siła, bez zgody Rady Bezpieczeństwa ONZ ${ }^{70}$.

Najbardziej niestabilnym krajem jest jednak Bośnia i Hercegowina, która na początku 2014 r. zaniepokoiła opinię publiczną burzliwymi protestami społecznymi o podłożu ekonomicznym, które były najbardziej gwałtowne od zakończenia wojny w $1995 \mathrm{r}$. Na gigantyczny nepotyzm kasty skorumpowanych urzędników, w większości wywodzących się z narodowości muzułmańskiej, którzy po wojnie przejęli władzę, skarży się znaczna część obywateli tego kraju. Największym problemem społecznym jest bezrobocie, które - wbrew oficjalnym, zaniżanym statystykom - sięgnęło 44\% i jest najwyższe w Europie ${ }^{71}$.

${ }^{69}$ Ibidem.

${ }^{70}$ Wciqż nieuznane przez Serbię Kosowo obchodzi 6. rocznice niepodległości, 17 II 2014, http://wiadomosci.onet.pl/swiat/wciaz-nieuznane-przezserbie-kosowo-obchodzi-6-rocznice-niepodleglosci/btvzc (dostęp 20 II 2014).

${ }^{71}$ J. Piaseczny, Gniew oszukanych Bośniaków, „Przegląd” 2014, nr 8, s. 29. 
Podobnie jak politycy tureccy, także mieszkańcy zwracają uwagę na absurdalna strukturę swego państwa, utworzona na mocy traktatu w Dayton. Jednak rewizja jego postanowień mogłaby na nowo obudzić „upiory przeszłości” w postaci konfliktów narodowościowych, które, choć zamrożone, to jednak nadal pozostają obecne w rzeczywistości bałkańskiej.

W kołach amerykańskich analityków coraz częściej pojawiają się twierdzenia o narastającej w Turcji opozycji między sekularyzmem a islamem, Zachodem a Wschodem. Rodzi się przy tym podejrzenie, że dbanie o własne interesy może kolidować z interesami Zachodu, zwłaszcza że w krajach arabskich Turcja nie jest już obecnie postrzegana jako eksponent interesów amerykańskich, ale jako obrońca islamu ${ }^{72}$. Czy nie brzmią niepokojąco słowa Turguta Özala, który wezwał potomków Imperium Ottomańskiego do zrealizowania historycznej misji, opartej na wizji tureckiego świata od Adriatyku do muru chińskiego ${ }^{73}$

W związku z rosnącym poparciem Ankary dla muzułmanów na Bałkanach może zachodzić podejrzenie o chęć reaktywowania władzy religijnej, sprawowanej przez sułtanów na całym terytorium Imperium Ottomańskiego. Jednak wydaje się nieprawdopodobne, aby Turcja powróciła do formy monarchii absolutnej. Ale inna forma, np. ustanowienie państwa teokratycznego, już wydaje się tam możliwa do urzeczywistnienia. Casus Iranu jest tego najlepszym przykładem. Prognozy rozwoju sytuacji wewnętrznej i zewnętrznej, związanej z Turcja, wskazują na to, że Ankara nie tylko nie zrezygnuje z opcji neoosmańskiej, lecz będzie ją rozwijać. Przykładem praktycznego sprawdzianu jej możliwości w stosunkach międzynarodowych jest aktywność w konflikcie syryjskim czy

${ }^{72}$ Ö. Taşpinar, op. cit., s. 14-15.

${ }^{73}$ D. Tanasković, op. cit., s. 22. 
palestyńskim. Turcja z zainteresowaniem obserwuje również kryzys bośniacki. Jej postawa świadczy więc o prowadzeniu wielowektorowej polityki zagranicznej, zgodnym także z podstawowymi założeniami idei neoosmańskiej. Nawet wewnętrzny kryzys, jaki dotknął Turcję w ciagu ostatnich kilkunastu miesięcy, nie zahamował impetu, z jakim prowadzona jest polityka tego państwa.

Zbigniew Brzeziński podkreślił, że jeśli demokratyczny eksperyment w Turcji zakończy się fiaskiem, to kraj ten może się zwrócić $w$ stronę apodyktycznej tożsamości islamskiej albo przyjać forme reżimu wojskowego. W obu wypadkach Turcja zamiast ostaniać Europę od problemów $i$ namiętności Bliskiego Wschodu, mogłaby przenieść je przez Batkany do Europy ${ }^{74}$.

Smilja Avramov, znana jugosłowiańska ekspertka w dziedzinie międzynarodowego prawa publicznego, podkreśliła, że Bałkany powinny pozbyć się cechującej je utopijnej iluzji o posiadaniu istotnej pozycji $\mathrm{w}$ stosunkach międzynarodowych. Sa one bowiem graczem podporządkowanym silniejszym podmiotom. Dzieje się tak ze względów historycznych i geopolitycznych, które odcisnęły piętno na tym obszarze, wyznaczajac jego dzieje ${ }^{75}$.

Ważne jest, aby dyktat silniejszych nie doprowadził do kolejnych podziałów na Bałkanach i nie eskalował następnych konfliktów. Wydaje się więc konieczne, aby Europa w większym stopniu skierowała swoje wysiłki i uwagę na wydarzenia, które zachodzą na tym obszarze, nie pozostawiając jego mieszkańców samym sobie, aby po raz kolejny w dziejach nie stały się zapalnikiem globalnego konfliktu.

${ }^{74}$ Z. Brzeziński, Strategiczna wizja. Ameryka a kryzys globalnej potegi, przeł. K. Skonieczny, Kraków 2013, s. 188.

${ }^{75}$ S. Šušić, op. cit., s. 32-33. 